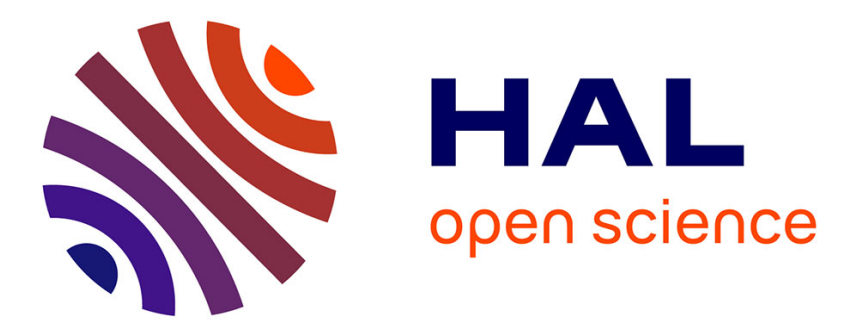

\title{
Infliximab as effective treatment for aseptic neutrophilic myositis
}

\author{
Perrine Guillaume-Jugnot, Sarah Guégan, Sarah Léonard-Louis, Stéphane \\ Barete, Olivier Benveniste, Yves Allenbach
}

\section{- To cite this version:}

Perrine Guillaume-Jugnot, Sarah Guégan, Sarah Léonard-Louis, Stéphane Barete, Olivier Benveniste, et al.. Infliximab as effective treatment for aseptic neutrophilic myositis. Neurology, 2019, 93, pp.1009 - 1011. 10.1212/wnl.0000000000008584 . hal-03523528

\section{HAL Id: hal-03523528 \\ https://hal.sorbonne-universite.fr/hal-03523528}

Submitted on 12 Jan 2022

HAL is a multi-disciplinary open access archive for the deposit and dissemination of scientific research documents, whether they are published or not. The documents may come from teaching and research institutions in France or abroad, or from public or private research centers.
L'archive ouverte pluridisciplinaire HAL, est destinée au dépôt et à la diffusion de documents scientifiques de niveau recherche, publiés ou non, émanant des établissements d'enseignement et de recherche français ou étrangers, des laboratoires publics ou privés. 


\section{Infliximab as effective treatment for aseptic neutrophilic myositis}

Perrine Guillaume-Jugnot, MD, * Sarah Guégan, MD, PhD,* Sarah Léonard-Louis, MD, Stéphane Barete, MD, Olivier Benveniste, MD, PhD, and Yves Allenbach, MD, PhD

Neurology ${ }^{\circledR}$ 2019;93:1009-1011. doi:10.1212/WNL.0000000000008584

Neutrophilic dermatoses are a heterogeneous group of inflammatory skin conditions all characterized by sterile neutrophilic infiltrates in cutaneous and subcutaneous tissues, usually leading to ulcers or erythematous plaques. They can be associated with extracutaneous sterile neutrophilic infiltration occurring mainly in the lung, liver, spleen, or lymph nodes, whereas aseptic neutrophilic myositis is extremely rarely reported. Isolated muscular neutrophilic infiltrates never occur in autoimmune myopathy, and this feature usually suggests an infectious muscle disease.

Recently, it was reported that pyoderma gangrenosum or necrotizing Sweet syndrome (2 distinct clinical entities belonging to the spectrum of neutrophilic dermatoses) may be mimickers of necrotizing fasciitis. ${ }^{1}$ The authors coined the unifying term of "necrotizing neutrophilic dermatosis" to define this subgroup of neutrophilic dermatoses with systemic inflammation and emphasized the importance of not misdiagnosing them as necrotizing fasciitis to avoid inappropriate management. We report herein 2 cases of severe aseptic neutrophilic myositis, which mimicked as well necrotizing fasciitis, although concomitant skin manifestations were mild or initially absent, and which responded dramatically to infliximab.

We examined a 47-year-old man with a mild painful proximal weakness and deep palpable subcutaneous nodules of the legs associated with high fever, night sweats, and leukocytosis. Electromyogram and creatine kinase levels were normal. The skin biopsy showed a neutrophilic panniculitis, and the muscle biopsy a neutrophilic myofasciitis, without infection. Malignancy and hemopathy were ruled out. Within the next weeks, following a diarrhea onset, Crohn disease was diagnosed. Initially, the patient was refractory to 4 weeks of corticosteroids $1 \mathrm{mg}$ per $\mathrm{kg}$ per day, but dramatically improved with infliximab $5 \mathrm{mg}$ per $\mathrm{kg}$.

A 75-year-old woman, bedridden, with a $23 \mathrm{~kg}$ weight loss, was also referred to our department for a neutrophilic myositis without initial cutaneous lesions. She had a history of Janus kinase 2 -mutated thrombocythemia, complicated with myelofibrosis. She was ambulant at disease onset and had developed during the last 3 years a proximal painful weakness, night sweats, and high fever with chronic blood inflammation (leukocytosis $28 \times 10^{9} / \mathrm{L}$ and C-reactive protein $121 \mathrm{mg} / \mathrm{L}$ ). Previous explorations showed asymmetric plurifocal myositis (thigh muscle MRI, figure) with a significant hypermetabolism in PET. Electromyogram showed myogenic features, and the creatine kinase level was normal. Myopathologic analysis revealed a disruption of muscle architecture with dense fibrosis, and polymorphic nodular inflammatory infiltrates mostly composed of altered neutrophils (figure). Muscle analysis ruled out infectious (including $16 \mathrm{~S}$ rRNA gene sequencing) or malignant diseases. Of note, various large spectrum antibiotic courses had been initiated without effect. She was also refractory to oral corticosteroids $1 \mathrm{mg}$ per $\mathrm{kg}$ per day during 3 weeks. When she arrived in our unit, she did not show any sign of skin involvement, but we considered this aseptic neutrophilic myositis as a neutrophilic

\author{
Correspondence \\ Dr. Guillaume-Jugnot \\ perrine.guillaumejugnot@ \\ gmail.com
}

*These authors contributed equally to the manuscript.

From the Sorbonne Université (P.G.J., O.B., Y.A.), INSERM UMRS_974, Center of Research in Myology, AP-HP, Department of Internal Medicine and Clinical Immunology, DHU I2B, PitiéSalpêtrière Hospital; Université Paris Descartes (S.G.), Service de Dermatologie, Hôpital Cochin-Centre Tarnier, APHP; Department of Neurology and Myology (S.L.-L.), Pitié-Salpêtrière Hospital; and Department of Dermatology (S.B.), Pitié-Salpêtrière Hospital, Paris, France.

Go to Neurology.org/N for full disclosures. Funding information and disclosures deemed relevant by the authors, if any, are provided at the end of the article.

Perrine Guillaume-Jugnot completed the list affiliations. 

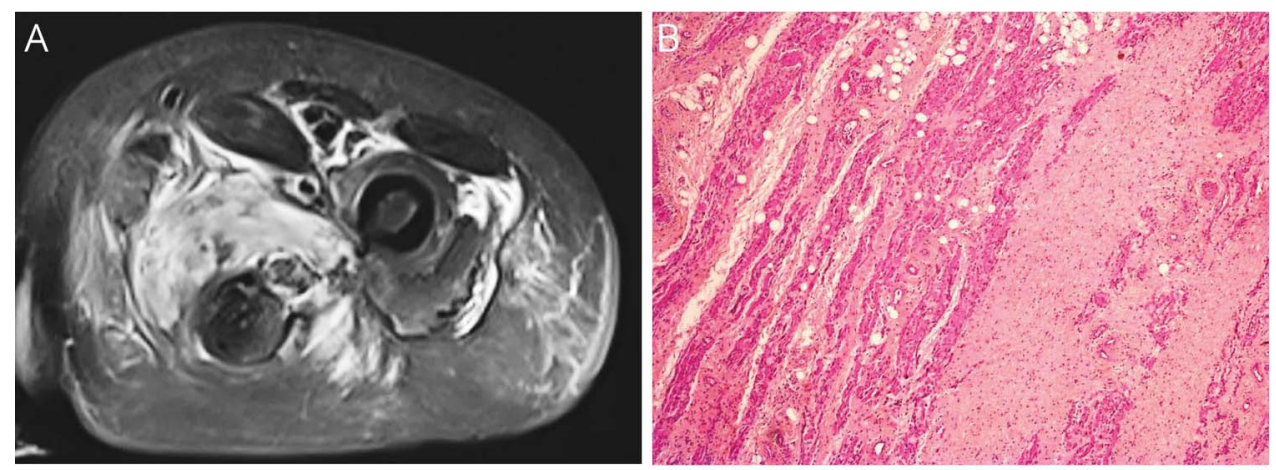

(A) Thigh muscle MRI STIR showing hypersignal within the following muscles: the vastus lateralis, the adductor longus, and the adductor brevis. There is also a moderate hypersignal on the gracilis muscle. No abnormal contrast in the fascia
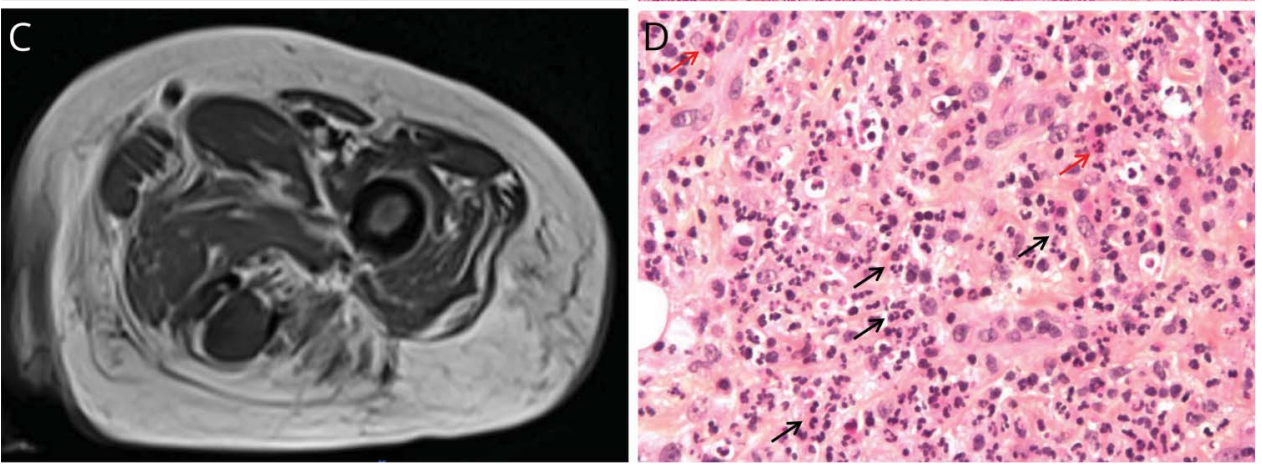
nor in the bone. (B) Hematoxylin and eosin staining of the vastus lateralis muscle biopsy showing fatty and fibrosis replacement (20x magnification). (C) Thigh muscle MRI T1 showing some degree of atrophia and fatty replacement, which mostly involved these muscles: the vastus lateralis, the biceps femoris, and the end of the gluteus maximus. (D) At higher magnification (200× magnification), the dense polymorphic nodular infiltrate is mainly composed of neutrophils (black arrows). Of note, few eosinophils are present (red arrows).

systemic disease associated with her acquired myeloproliferative disorder. She quickly and dramatically improved (apyrexia and C-reactive protein level normalization) following infliximab initiation ( 1 infusion $5 \mathrm{mg}$ per $\mathrm{kg}$ followed by 1 infusion 2 and 8 weeks later) regaining the use of her limbs. Because of an early immunization against infliximab, she relapsed developing concomitantly an erythematous and edematous plaque, without skin breakdown, of the left leg. She responded to a second line of treatment with tocilizumab and without antibiotic therapy.

Five other cases of histologically confirmed aseptic neutrophilic myositis without skin manifestations ${ }^{2-4}$ or skin breakdown ${ }^{5,6}$ have been reported. Muscle histology always showed neutrophilic infiltrates, with necrosis in 3 cases. Creatine kinase levels were normal $(\mathrm{n}=1)$ or high $(\mathrm{n}=3)$ between 467 and $4471 \mathrm{UI} / \mathrm{L}$ and not available in 1 case. Aseptic neutrophilic myositis was associated with acute myeloid leukemia $(\mathrm{n}=2)$, myeloproliferative disorder $(\mathrm{n}=$ $1)$, inflammatory bowel disease $(n=1)$, or was the unique feature $(n=1)$. All patients were treated with corticosteroids and achieved remission, except for 1 who died of myocardial infarction. The use of tumor necrosis factor (TNF) alpha inhibitors has proved safe and effective in other neutrophilic dermatoses such as pyoderma gangrenosum, especially when associated with underlying diseases such as inflammatory bowel diseases, rheumatoid arthritis, or ankylosing spondylitis. ${ }^{7}$ We here report the first 2 cases of aseptic neutrophilic myositis, one of which developing concomitantly Crohn disease, that responded dramatically to a TNF-alpha inhibitor.

This rare condition shows that extracutaneous organs may be solely affected by aseptic neutrophilic infiltration; it can nevertheless be considered as part of the spectrum of neutrophilic dermatoses sine dermatosis and as a variant of the necrotizing neutrophilic dermatosis mimicking necrotizing fasciitis. ${ }^{1}$ The mainstay of treatment remains systemic corticotherapy, but in cases of resistance or contraindication, TNF-alpha inhibitors, namely infliximab, should be considered as alternative therapy.

\section{Author contributions}

P. Guillaume-Jugnot: drafting/revising the manuscript, data acquisition, study concept or design, accepts responsibility for conduct of research and will give final approval, and acquisition of data. S. Guégan: drafting/revising the manuscript, data acquisition, study concept or design, analysis or interpretation of data, accepts responsibility for conduct of research and will give final approval, and study supervision. S. Léonard-Louis: analysis or interpretation of data, accepts responsibility for conduct of research and will give final approval, and acquisition of data. S. Barete: drafting/revising the manuscript, analysis or interpretation of data, accepts responsibility for conduct of research and will give final approval, and acquisition of data. $\mathrm{O}$. Benveniste: drafting/revising the manuscript, analysis or interpretation of data, accepts responsibility for conduct of research and will give final approval, acquisition of data, and study 
supervision. Y. Allenbach: drafting/revising the manuscript, data acquisition, study concept or design, analysis or interpretation of data, accepts responsibility for conduct of research and will give final approval, and study supervision.

\section{Acknowledgment}

The authors thank Quentin Monzani, who helped us actively for the MRI pictures, and Gonzague de Pinieux and Elodie Miquelestorena-Standley for the histology.

\section{Study funding}

No targeted funding reported.

\section{Disclosure}

The authors report no disclosures relevant to the manuscript. Go to Neurology.org/N for full disclosures.

\section{Publication history}

Received by Neurology April 21, 2019. Accepted in final form September 3, 2019.

\section{References}

1. Sanchez IM, Lowenstein S, Johnson KA, et al. Clinical features of neutrophilic dermatosis variants resembling necrotizing fasciitis. JAMA Dermatol 2019;155:79-84.

2. Kim MK, Park JW, Park SH, et al. Neutrophilic myositis without cutaneous involvement as the first manifestation of acute myeloid leukemia. Korean J Intern Med 2005;20:346-348.

3. Mosnier E, Rousset P, Hugol D, Bouscary D, Aslangul E. Neutrophilic myositis sine dermatitis in a neutropenic patient with myelodysplastic syndrome. Ann Hematol 2013;92:551-552.

4. Lee KH, Han KM, Kim EJ. A case of neutrophilic myositis. J Rheum Dis 2017;24:161.

5. Attias D, Laor R, Zuckermann E, et al. Acute neutrophilic myositis in Sweet's syndrome: late phase transformation into fibrosing myositis and panniculitis. Hum Pathol 1995;26:687-690.

6. Qureshi JA, Staugaitis SM, Calabrese LH. Neutrophilic myositis: an extra-intestinal manifestation of ulcerative colitis. J Clin Rheumatol 2002;8:85-88.

7. Brooklyn TN, Dunnill MGS, Shetty A, et al. Infliximab for the treatment of pyoderma gangrenosum: a randomised, double blind, placebo controlled trial. Gut 2006;55: 505-509.

\section{Subspecialty Alerts by E-mail!}

Customize your online journal experience by signing up for e-mail alerts related to your subspecialty or area of interest. Access this free service by clicking on the "My Alerts" link on the home page. An extensive list of subspecialties, methods, and study design choices will be available for you to choose from-allowing you priority alerts to cutting-edge research in your field!

\section{AAN Online Learning Center}

Browse a variety of online CME, self-assessment, and other learning activities to suit your wide-ranging interests and learning styles. Visit Learning.AAN.com today to access the Online Learning Center, your exclusive member-only hub for AAN continuing medical education.

\section{Share Your Artistic Expressions in Neurology 'Visions'}

AAN members are urged to submit medically or scientifically related artistic images, such as photographs, photomicrographs, and paintings, to the "Visions" section of Neurology ${ }^{\circ}$. These images are creative in nature, rather than the medically instructive images published in the NeuroImages section. The image or series of up to six images may be black and white or color and must fit into one published journal page. Accompanying description should be 100 words or less; the title should be a maximum of 96 characters including spaces and punctuation.

Please access the Author Center at NPub.org/authors for full submission information. 


\section{Neurology}

\section{Infliximab as effective treatment for aseptic neutrophilic myositis \\ Perrine Guillaume-Jugnot, Sarah Guégan, Sarah Léonard-Louis, et al. Neurology 2019;93;1009-1011 Published Online before print October 29, 2019 \\ DOI 10.1212/WNL.0000000000008584}

This information is current as of October 29, 2019

\section{Updated Information \& Services}

References

Subspecialty Collections

Permissions \& Licensing

Reprints including high resolution figures, can be found at: http://n.neurology.org/content/93/23/1009.full

This article cites 7 articles, 1 of which you can access for free at: http://n.neurology.org/content/93/23/1009.full\#ref-list-1

This article, along with others on similar topics, appears in the following collection(s):

All Clinical Neurology

http://n.neurology.org/cgi/collection/all_clinical_neurology Muscle disease

http://n.neurology.org/cgi/collection/muscle_disease

Information about reproducing this article in parts (figures,tables) or in its entirety can be found online at:

http://www.neurology.org/about/about_the_journal\#permissions

Information about ordering reprints can be found online:

http://n.neurology.org/subscribers/advertise

Neurology ${ }^{\circledR}$ is the official journal of the American Academy of Neurology. Published continuously since 1951, it is now a weekly with 48 issues per year. Copyright @ 2019 American Academy of Neurology. All rights reserved. Print ISSN: 0028-3878. Online ISSN: 1526-632X.

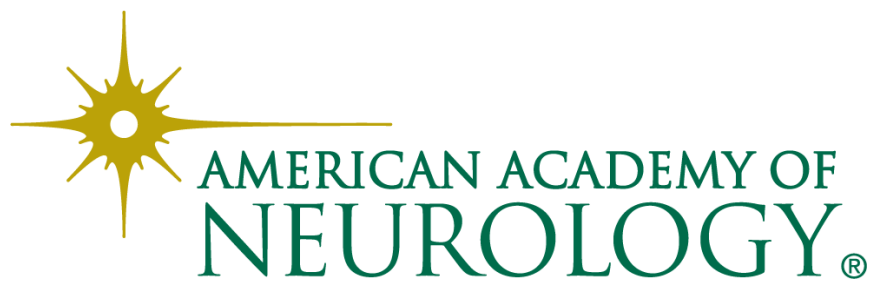

